lyzed under either traditional or realistic views of assent. ${ }^{2}$ The doctrine of business compulsion, the most modern extension of duress, depends upon proof of very serious pressure, illegal under independent circumstances. ${ }^{43}$ However, the use of legal pressures to obtain undeserved benefits may be just as reprehensible. The expenses and delay of litigation, for example, make the threat of suit a formidable weapon..$^{4}$

If legislative and judicial controls were directed at affording parties a fair opportunity of gauging their own bargain, it is doubtful whether widespread policing for unconscionability would be necessary. The parties, rather than the courts, are still considered to be the best judges of their bargain, and their promises, freely given, should continue to be enforced.

However, the language of the code provision would make extensive judicial policing of contracts possible. Early comments indicated that such surveillance was intended; the present draft fails to preclude observance of such a purpose in judicial interpretation. Perhaps the omission of mention of general judicial control in the present comment indicates that the commissioners have experienced a change of heart, but that comment cannot be expected to control development of the provision. If the draftsmen do not wish to enact something similar to "equity's ancient policy" as part of sales law, the statute must be rewritten. It can no longer be couched in broad terms of unconscionability. It must concentrate on particular problems toward whose solution it is directed.

\title{
LOSS SPLITTING IN CONTRACT LITIGATION
}

With rare exception Anglo-American legal tradition has regarded financial and economic losses as burdens to be borne completely by either one individual or another. The major task of the courts has been that of shifting the burden from the party suffering the loss to the party "causing" it. In cases where this could not be accomplished, the loss was then said to "lie where it falls."

The application of this primitive notion to the more complex legal relations of present-day life often leads to unjust results. In some situations efforts to remedy these inequities have been made. Thus, when a loss has been suffered because of the fault of more than one individual, damages may be apportioned among the wrongdoers. ${ }^{x}$ Losses resulting from the negligence of both the in-

${ }_{42}$ Sharp, Promissory Liability II, 7 Univ. Chi. L. Rev. 250, 263-68 (I940); Sharp, Williston on Contracts, 4 Univ. Chi. I. Rev. 30, 38 (I936); Sharp, Notes on Contract Problems and Comparative Law, 3 Univ. Chi. L. Rev. 276, 285 (1936); Extension of Relief for Unilateral Mistake, $x_{7}$ Univ. Chi. L. Rev. 725 (1950).

43 Hartsville Oil Mill v. United States, 27x U.S. 43 (I926); Doctrine of "Business Compulsion," 79 A.L.R. 655 (1932).

44 Sharp, op. cit. supra note 9 , at 786.

× N.C. Gen. Stat. (Michie, I949) \& I-240; Pa. Stat. Ann. (Purdon, Supp. 1949) tit. I2, \& I4I; Scharine v. Huebsch, 203 Wis. 26I, 234 N.W. $35^{8}$ (I93 r). 
jured and defendant have traditionally been distributed between both parties in admiralty, ${ }^{2}$ and recent attempts have been made to distribute such losses in municipal law under comparative negligence statutes. ${ }^{3}$ In England, following the now famous Fibrosa case, ${ }^{4}$ Parliament provided for a more equitable allocation of losses suffered as a result of a contract's becoming impossible of full performance. Thus under the Law Reform (Frustrated Contracts) Act ${ }^{5}$ when a party to a contract impossible of full performance has both obtained a benefit and incurred expenses in pursuing the contract, in making restitution for the benefit he may deduct for the expenses incurred to the extent that the court deems it just. The Act, however, although providing a means of equitable loss sharing, appears unduly restricted in scope. In contrast to this British attempt, little effort has been made in Illinois and elsewhere in the United States to rectify the inequities which may result when a loss is suffered by individuals none of whom is at fault. A consideration of "impossibility" as a typical situation in which these inequities arise and of the mechanics necessary to avoid the resulting injustice may serve to illustrate that in this and comparable situations equitable results cannot be achieved by any form of complete loss shifting, but must be obtained through loss splitting.

It is now well settled doctrine in Illinois that in the absence of an assumption of risk by the parties, either expressly or impliedly in the contract, performance of a contract is excused when it becomes prohibited by law, ${ }^{6}$ when a specific thing whose existence is essential to performance is destroyed without fault of the parties, ${ }^{7}$ and in the case of a personal service contract, when the promisor dies or becomes physically incapacitated. ${ }^{8}$ When it has been decided

${ }^{2}$ The Schooner Catherine v. Dickinson, I 7 How. (U.S.) I7o (1855); The Eugene F. Moran, 212 U.S. 466 ( $x 909)$.

3 Miss. Code Ann. (I942) $\S \S$ r454-55; Neb. Rev. Stat. (I948) $\S 25-$ II5 r; Wis. Stat. (Brossard I933) § 331.045; Ont. Stat. 20 Geo. V, C. 27 (I930) amended in 2 I Geo. V, c. 26 (I93I).

4 Fibrosa Spolka Akcyjna v. Fairbairn Lawson Combe Barbour, Ltd., [1943] A. C. 32.

56 \& 7 Geo. VI, c. 40 (I940). See McNair, The Law Reform (Frustrated Contracts) Act, I943, 60 I.Q. Rev. $\mathrm{x} 60$ (1944). Similar steps have been taken on the continent in order to cope with problems growing out of the great social and economic upheavals of the two wars. Several doctrines were developed, e.g., the so-called "doctrine de l'imprevision" of the French legal system (see 2 Colin et Capitant, ro ed. (r948) § 130 ) and the "doctrine of change of the foundations of the transaction" of the German system (see Enneccerus-Lehmann, Lehrbuch des buergerlichen Rechts. Schuldverhaeltnisse. I2 ed. (1932) I59; Esser, Lehrbuch des Schuldrechts (I949) I6I). In both countries legislative regulation was found to be necessary. (France: esp. Loi Faillot of 2I January I918; Germany: Decree of 30 November r939 (RGBl. I 2329); Third Currency Law, of I948, U.S. Zone of Control, Law No. 63, § 2I; cf. Harmening and Duden, Waehrungsgesetze (I949) 27r.)

${ }^{6}$ Young Machinery Co. v. Lee Loader and Body Co., 218 Ill. App. 427 (I920).

${ }_{7}$ Siegel Cooper \& Co. v. Eaton \& Prince Co, I65 Ill. 550, 46 N.E. 449 (I896); Huyett \& Smith Co. v. Edison Co., I67 Ill. 233, 47 N.E. 384 ( 1897 ).

${ }^{8}$ Smith v. Preston, I70 Ill. I79, I48 N.E. 688 (I897); White v. White, 274 Ill. App. 53 I (r934). 
that full performance of a contract will be excused,9 the question arises as to what allocation should be made of losses reasonably incurred in performing the contract or in reliance on the expectation that the contract would be performed. An examination of Illinois cases will indicate the present inadequacy of loss distribution schemes.

It will be helpful to discuss the cases in terms of the restitution, reliance, and expectation interests in contract damages. When further performance of a contract is excused on the basis of impossibility the courts are in effect refusing to protect the so-called expectation interest. ${ }^{10}$ The loss arising from the defeat of future expectations is to be borne by the party suffering it since neither party has assumed the risk of the loss and it has arisen without the fault of either party to the contract. The restitution interest, designed to prevent unjust enrichment, is protected when a court orders a return of or payment for the "benefit" received under a contract which has become impossible of full performance. ${ }^{\text {II }}$ For example, in White v. White ${ }^{12}$ it was held that when a personal service contract to manage a building, collect rents, and make leases was prematurely terminated upon the death of the manager, the personal representatives of the deceased were entitled to recover for the reasonable value of the services already performed. The reliance interest is protected when damages are awarded to compensate for losses or other changes of position reasonably incurred in reliance on the contract's being fully performed.. ${ }^{23}$ An expense or change of position incurred in furthering one's own performance of a contract subsequently terminated because of impossibility is an essential reliance loss. ${ }^{14}$ While this concept may also embrace the restitution interest, a strict reliance may be defined so as to exclude the change in position which serves to benefit the other party to the contract. A detrimental change of position taken in the expectation that the contract would be fully performed by the other party is an incidental reliance loss. ${ }^{25}$ To the extent that incidental reliance may overlap the expectation interest it will be necessary in the subsequent discussion to distinguish between essential and incidental reliance.

In considering the effect of the accidental destruction of a building upon a contract to install a ventilating system therein, the court in Huyett $\mathbb{S}^{\circ}$ Smith Co. v. Chicago Edison $\mathrm{Co}^{16}$ held that while both parties were excused from further

9 It will not be the purpose of this note to identify the fictional and conceptual bases by which the impossibility doctrines have been adopted nor to consider to what extent they may be extended to include the "frustration of contractual purpose" situation. See Contracts,

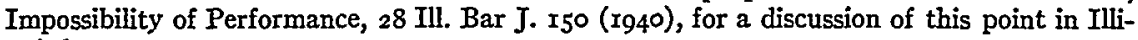
nois law. (1937).

${ }^{20}$ Fuller and Perdue, The Reliance Interest in Contract Damages: 2, 46 Yale L.J. 373, 379

II Ibid., The Reliance Interest in Contract Damages: 1 , ibid., at 53 .

12274 Ill. App. 53 I (r934).

${ }^{13}$ Fuller and Perdue, op. cit. supra note ro, at 54. $\quad$ 15 Ibid.

14 Ibid., at 78 .

${ }^{16}$ I67 Ill. 233,47 N.E. 384 (1897). 
performance of the contract, neither was entitled to recover anything for a part performance thereof. ${ }^{17}$ The contract in question was between a subcontractor and contractor rather than contractor and owner so that the materials furnished by the subcontractor did not become the property of the defendant. The White ${ }^{18}$ case may be distinguished on the grounds that part performance resulted in some benefit to the defendant while in the Huyett \& Smith case no benefit moved to the prime contractor. Taken in this sense the court in the Huyett \& Smith case was refusing to protect the strict reliance interest. Moore v. Robinson, ${ }^{x 9}$ however, seems in opposition to any notion that in impossibility cases only restitution damages will be awarded to the exclusion of the reliance interest. Under the contract in this case Robinson had agreed to defend and secure the acquittal of Moore's brother who had been charged with a criminal offense. The retention of the fee was conditioned upon the accused's acquittal and release. To the surprise of both and without the fault of either party to the contract the accused never appeared to answer the indictment. The court, without considering whether Moore had received any benefit, held that "what [Robinson] in good faith did pursuant to the terms of the agreement, before ascertaining that its performance had become impossible, he is entitled to compensation for. ...",

The inconsistent positions taken by the Illinois courts in the Huyett 8 Smith and Robinson cases possibly may be accounted for on the grounds that no rational and equitable means of allocating or shifting the entire loss involving the essential reliance interest can be devised. On the one hand, contract damages generally are associated with broad notions of fault, or assumption of risk, and are awarded, although not as punishment, in order to make good the "losses caused" by the acts of the party at fault.2. However, the notion of fault is foreign to the impossibility cases discussed here. Furthermore, the event or mishap which has relieved the parties from further performance was unforeseen and neither party has assumed the risk of the losses arising therefrom. On the other hand, damages in quasi-contract or restitution damages are awarded in order to avoid the unjust retention of a benefit received by one person from

\footnotetext{
I7 Compare Siegel Cooper \& Co. v. The Eaton \& Prince Co., 165 Ill. $55^{\circ}, 46$ N.E. 449 (I896) (refusing to award damages for part performance, but awarding damages on the grounds that the contract was severable). But see Schwartz v. Saunders, 46 Ill. I8 (r867) (enforcing a mechanics lien for a part performance on a building to be erected by another contractor, but partly on the grounds that the defendant wrongfully refused to pay under an apportionable contract); Clarke v. Busse, 82 Ill. $5 I_{5}$ (I876) (subcontractor recovering for part performance on a structure subsequently destroyed on the grounds that he is "not responsible for the destruction of the main work undertaken by the contractor and being prevented by no fault of his from completing his agreement, on the doctrine of Schwartz v. Saunders he would be entitled to recover for work actually done." At 518.)

${ }^{8} 274$ IIl. App. 53 I (1934).

${ }^{29} 92$ Ill. 49 r (I879). ${ }^{20}$ Ibid., at 493.

"See Gahan, Mayne's Treatise on Damages 9 (Ioth ed., I927).
} 
another. ${ }^{22}$ But the losses which involve the strict reliance interest exclude by definition the notion of benefit to the party from whom damages are sought. Because none of the ordinary damage notions are strictly applicable to these losses, the courts by means of artificial rationalizations may vacillate from one position to another in order to reach what they consider to be more equitable results in each case. At least one court, however, has openly admitted the inadequacy of present loss distribution schemes involving the reliance interest, but has contended that it is the function of the legislature, not the courts, to alter them. ${ }^{23}$

Two questions then arise: ( $\mathrm{I}$ ) What more equitable scheme for allocating strict reliance losses can be devised? (2) Assuming that such a scheme is devised, may the courts initiate its use on their own, or must the moving force come from the legislatures?

Since both parties are by assumption without fault and by definition the loss suffered by one party has not resulted in a commensurate benefit to the other, the principle of equal treatment of equals would seem to indicate that unless the parties have provided for the allocation of these losses in their contract, the burden of the loss should be shared by both parties. ${ }^{24}$ In view of the fact that both parties are faultless this would follow whether the loss has been suffered by the party whose performance has become impossible or by the party still able to perform. ${ }^{25}$ Since this principle of loss sharing appears to be a frequently proposed ${ }^{26}$ but seldom practiced remedy, a few hypothetical cases will be helpful in illustrating the factors to be taken into consideration in attempting to execute such an allocation.

CASE I: Plaintiff has agreed to install an elevator in defendant's building.

2 Woodward, The Law of Quasi Contracts $\S$ I (19r3).

${ }_{23}$ Fibrosa Spolka Akcyjna v. Fairbairn Lawson Combe Barbour, Ltd., [r943] A. C. 32, 49.

${ }^{44}$ See Sharp, Promissory Liability, 7 Univ. Chi. L. Rev. 250, 269 (r940); Corbin, Frustration of Contract in the United States of America, 29 J. Comp. Leg. \& Int. L., 3rd Series, Part III-IV, I, 8 (r947).

25 See 6 Williston, Contracts $\S 1972$ (I938). "It should make no difference whether the party seeking quasi contractual relief [for part performance of a contract terminated because of impossibility] is the one who has failed, because of impossibility, to fulfill his contract or whether it is the other party who has rendered performance. In both cases performance of the contract has been stopped midway without fault on either side."

It would also appear that the question of insurance is irrelevant to the present issue of loss distribution unless one of the parties to the contract is obliged to insure since the insurance company protecting the loss would probably be given subrogated rights. See 128 Parliamentary Debates, Lords, Law Reform Act, I44 et seq. (I942-3); Law Reform (Frustrated Contracts) Act, I943, $6 \&$ 7, Geo. VI c. 40 .

${ }^{26}$ Note 24 supra. Its application has also been suggested in the case of a loss between innocent parties as a result of a third party's fraud. Radin, The Victims of Fraud, Book Review, 2I Calif. L. Rev. 293, 294 (1933); in a contest between innocent holders of legal and equitable estates with losses resulting from a third party's fraud. Jenks, The Legal Estate, $24 \mathrm{~L}$. Q. Rev. I47, 155 ( 1908 ); and in the case of successive bona fide converters of a negotiable stock certificate. Reconsideration of Share Certificate Negotiability, 7 Univ. Chi. I. Rev. 497, 5 Ig (I940). 
The contract price is $\$ 2,500$. Nothing has been said about time or terms of payment. When the plaintiff has expended $\$ 800$ in preparing to install the elevator but before any part of the installation has been made, the building is destroyed by accidental fire. The preparations have consisted primarily of procuring and readying specialized materials which were to be used in the installation and which because of their specialized nature and adaptation have a present market value of only \$roo. While it is clear that further performance on the contract would be excused, ${ }^{27}$ under present loss distribution schemes in Illinois the plaintiff would probably bear the complete loss for the materials purchased and work done. ${ }^{28}$ Under a principle of equal sharing of essential reliance losses, since the net loss is $\$ 700$, the plaintiff could recover $\$ 350$ from the defendant.

CASE II: Assume the same contract but in this situation the building is destroyed when the installation is one half completed. The value of the plaintiff's services and materials already installed is $\$ \mathrm{I}, 250$. The question arises whether the cost of part performance by the plaintiff should be treated as an essential reliance interest in which case the loss would be split or as a restitution interest in which case the defendant would be required to pay the "value" of the "benefit" received. ${ }^{29}$ The question reduces itself to whether the defendant has received some "benefit" from the part performance. It has been suggested by some that under contracts to do work upon an existing structure, title to the materials and the results of the work passes to the owner of the structure as the work progresses, and therefore the owner receives some "benefit" however temporary: ${ }^{30}$ Thus in accordance with traditional title and risk of ownership notions, the plaintiff would be entitled to complete restitution damages. It should be noted, however, that in the case of construction from the ground up as distinguished from work upon an existing structure, the ordinary association of risk with title is prevented by the familiar rule that the contractor assumes the risk of accidental destruction. Here, when there is accidental destruction, a contractor cannot recover under a restitution theory for part performance. ${ }^{3 \mathrm{x}}$ Moreover, in many cases conceptual difficulties may arise in regard to the "benefit" realized by the owner from part performance. For example, assume a contract providing for the demolition of three stories of a structure which is then completely destroyed by fire. In such a case there can be no title to the

${ }^{27}$ Cases cited note 7 supra.

${ }^{28}$ Cases cited notes 16 , 17 supra.

29 With restitution damages the cost to the plaintiff and the value of the benefit to the owner usually coincide. When there is a deviation a question arises as to which amount the plaintiff is entitled to recover. Although there is dispute, the measure is generally the reasonable cost to the plaintiff rather than the benefit value to the defendant. See Moore v. Robinson, 92 Ill. 49I (r879); Quasi Contractual Recovery for Part Performance of a Contract, 44 Harv. L. Rev. 623 (r93 I).

${ }^{30} 6$ Williston, Contracts $\S 1976$ (1938). Contra: Appleby v. Meyers, L.R. 2 C.P. 65 I (I867).

${ }^{3 x}$ See cases collected 53 A.L.R. I06. (I928). 
materials passing to the owner as the work progresses, from which the owner can be said to derive a benefit. It may be this conceptual difficulty with regard to benefit that has prompted some courts to refuse to award any recovery for part performance..$^{32}$ In justifying such a refusal courts have argued that when a contract is for an entire performance the plaintiff is not entitled to recover for any part performance. ${ }^{33}$ In using the distinction between entire and divisible or separable contracts, however, courts are often presented with a difficult question of interpretation. For while the parties in some cases may clearly indicate that no liability for part performance will be assumed, the question of reward for part performance more often arises where no such indication is given. ${ }^{34}$

Under the English Law Reform (Frustrated Contracts) Act ${ }^{35}$ no distinction is made between restitution and reliance losses. Thus the cost of labor and materials already installed as well as strict reliance losses may be split. Under this view in the supposed case the plaintiff would be entitled to recover $\$ 625$, whereas if it is said that the owner has received a benefit and bears the risk of ownership for the work already installed by the plaintiff, then the plaintiff is entitled to recover the $\$ I, 250$.

CASE III: Assume the fact situation of Case I where plaintiff has incurred expenses without any commensurate benefit to the defendant, but consider the additional factor of plaintiff's having made a bad bargain. Thus while the contract price was $\$ 2,500$, as a result of changing market conditions the cost of plaintiff's labor and materials when the building was destroyed was already $\$ 3, \infty 00$. There would seem to be little justification in having the defendant bear any part of the loss resulting solely from the plaintiff's bad bargain. Thus that portion of the plaintiff's total loss which defendant should be made to bear should be limited at least by a pro-rata portion of the total contract price. ${ }^{36}$ If in the instant example it could be determined that at the time of destruction

${ }^{32}$ See Huyett \& Smith Co. v. Chicago Edison Co., note 16 supra; Appleby v. Meyers, L.R. 2 C.P. 65 I (1867).

33 Ollinger \& Bruce Dry Dock Co. v. James Bibboney \& Co., 202 Ala. 5I6, 8I So. I8 (Igr8); Clark v. Collier, $100 \mathrm{CaI} .256,34$ Pac. 677 (1893). The distinction between entire and severable contracts is also frequently followed in cases involving a contract to construct from the ground up. School District v. Dauchy, 25 Conn. 530 (r857); Vogt v. Hecker, II8 Wis. 306, 95 N.W. 90 (1903); cases cited 53 A.L.R. I03 (1928).

34 Some courts have awarded damages to a contractor for part performance on the theory that the owner of a structure impliedly undertakes to keep the structure in existence until the work is completed. Niblo v. Binssee, I Keyes (N.Y.) 476 (r864); see Rawson v. Clark, 7o Ill. 656 (I873). But it has been pointed out that if this reasoning were sound, when the structure was destroyed, the contractor could recover expectation damages-a contention which has never been supported by the cases. Woodward, The Law of Quasi Contracts $\$$ II8 (I9I3); 6 Williston, Contracts $\S \mathrm{I}_{97} 6$ ( $\mathrm{I}_{93} 8$ ).

35 Note 5 supra.

${ }^{36}$ See Clark v. Gilbert, 26 N.Y. 279 (I863); Matter of Buccini v. Paterno Construction Co., 253 N.Y. 256 , r7o N.E. 9 ro (r930) (limiting restitution damages to a pro-rata portion of the contract price). 
the plaintiff had performed one half of the total job (although this may not result in the elevator's being one-half installed), then plaintiff's recovery should not exceed $\$ 1,250 .{ }^{37}$ By using such a limit in the sharing of essential reliance losses the danger of a defendant's being unduly burdened by the erroneous business judgments of a plaintiff will be avoided.

CASE IV: In a case where the contractor in completing one half of the job has kept his costs well below a pro-rata portion of the contract price, it does not follow from Case III that the owner-defendant when he has received no benefit should be expected to pay more than his share of the actual losses although less than one half of the contract price. If the total cost of labor and materials was $\$ \mathrm{r}, 000$, although a pro-rata portion of the contract price equaled $\$ \mathrm{I}, 250$, the contractor should not recover from the defendant more than $\$ 500$ in damages. This follows because damages are to be awarded not on a principle of quantum meruit, or in strict accordance with the terms of the contract, but on the basis of a fair and equitable distribution of unanticipated losses arising from accidental mishap in the performance of the contract. ${ }^{38}$

CASE V: Up to this point we have considered situations where the strict essential reliance losses are suffered only by the party whose performance has been made impossible. A situation where strict essential reliance losses are suffered by both parties may arise where both parties to the contract are obligated to give performance in kind. Thus in exchange for the contractor's installation of the elevator, the owner of the building may have agreed to give the contractor a two-year lease on an apartment in the building. Money expended by the owner in readying the apartment for occupancy is also an essential reliance loss, and should be shared in the same way as the contractor's expenses. Again a pro-rata portion of the contract price, or an evaluation thereof, should set a maximum limit on recovery, but with recovery still not exceeding actual expenses incurred. Assuming \$200 was spent by the owner, \$10o could be deducted from the amount that the contractor was to recover to compensate him for his reliance losses.

CASE VI: Frequently cases will arise in which one party to a contract has suffered reliance losses while the other party is entitled to restitution damages. The most common example of this situation may be in the case where there has been a prepayment on the one side and reliance losses on the other when further

\footnotetext{
${ }^{37}$ A question arises whether since this is a case of splitting reliance losses the limit should be the pro-rata portion of the contract price or one half thereof. On the one hand, the use of of the undivided portion as an upper limit will serve to limit the defendant's liability in accordance with his original expectations; but on the other hand the use of this higher limit may enable the plaintiff to recoup from the defendant a part of his losses which, if the contract had been completed, he would not have been able to realize.

${ }^{38}$ See Matter of Buccini v. Paterno Construction Co., 253 N.Y. 256, 258, x70 N.E. 910 , 9 II (I930), in which Cardozo, J. said: "The award will then conform to the principles of liability in quasi contract and to the considerations of equity and justice by which that liability is governed ... the controversy is one that has its origin in the contract and in the performance of the work thereunder."
} 
performance of the contract is excused. ${ }^{39}$ The American rule generally is that the payer may recover from the payee what he has paid minus the value of what he has received.40 The old English rule had been that the "loss lies where it falls," the payer thereby losing the prepaid amounts..$^{4}$ The recent alteration of this distribution scheme in England has resulted in the payer being allowed to recover the sums paid minus the expenses incurred by the payee for the purpose of performing the contract if and to the extent that the court deems it just. ${ }^{22}$ The advantage of this scheme over the American rule in that it includes essential reliance losses is apparent.

Another case is presented where party $A$ has incurred expenses in performing a contract but has received from $B$, the other party to the contract, some benefit other than prepayment. While the essential reliance losses should be split, B should be able to deduct from his contribution to $A$ for reliance losses the amount of restitution damages to which he is entitled. Conversely where $A$ is entitled to both restitution and contribution by $B$ the value of the benefit received by $B$ should be added to his pro-rata share of reliance losses in determining the extent to which $B$ should be liable.

CASE VII: The question now arises whether incidental reliance losses should also be distributed in the same way as essential reliance losses. Expenses incurred by the owner in advertising the installation of the new elevator may serve as an example of this kind of loss. On the one hand, as in the case of essential reliance, both parties are in the same position with respect to culpability. On the other hand, the award of reliance damages to compensate in whole or in part for incidental reliance losses may run contrary to the notion that further performance of the contract is excused, or that expectation damages will not be awarded, since the same elements of loss may appear in both damage categories. Unless the contract price serves as a limit on the amount of incidental damages awarded, the case can easily be imagined where an award for incidental reliance losses would be greater than the cost of full performance of the contract would have been; yet both parties are excused from further performance. However, it has been demonstrated that in the ordinary suit for breach of contract there is no rational connection between the contract price and the nature of the loss which the incidental reliance interest is designed to protect.43 Thus it is with regard to incidental reliance losses that the argument is most persuasive that to award damages would involve a complete rewriting of the contract.44

39 Fibrosa Spolka Akcyjna v. Fairbairn Lawson Combe Barbour, Ltd., [1943] A. C. 32.

$1^{10}$ Rest., Contracts $\$ 468$ (r932).

$4^{2}$ Chandler v. Webster, [1904] I K.B. 493 .

42 Note 5 supra.

${ }^{43}$ Fuller and Perdue, op. cit. supra note io, at 78.

${ }_{44}$ See J. Wills in Blakeley v. Muller, [rg03] 2 K.B. $760 \mathrm{n}$., $762 \mathrm{n}$. "The process of constructing a hypothetical contract by supposing what terms the parties would have arrived 
Attention can now be turned to the question whether a more equitable loss distribution scheme can be initiated by the courts without prior authorization by the legislature. Any loss distribution scheme imposed by the courts is an allocation of risk upon the happening of an event which the parties have failed to anticipate and for which they have failed to provide. 45 The argument has been made that excusing performance on the basis of impossibility, mistake, or on any other grounds, is in itself an allocation of risk. If a court can read into a contract an "implied condition" which will excuse performance, it is not a radical step also to read in a fair and reasonable provision for allocation of the losses arising therefrom. $4^{6}$ However, courts appear reluctant to provide for the innovation of a fair loss distribution scheme on their own. In addition to overcoming the courts' reluctance, or inertia, legislative action in the field could insure by the use of broad terminology that loss sharing would be applied not on the basis of mere precedent, but in accord with the equitable policy underlying the statute. Thus the type of allocation described could apply not only to construction contracts terminated on the basis of impossibility, but to all cases where faultless mistake or physical mishap results in performance of the contract being excused or modified and where the parties have failed to anticipate such an event. For example, in the case of mutual mistake an allocation of the strict essential reliance losses would involve the same considerations as in the examples previously discussed.47 In both situations neither party is at fault and the risk for such losses has not been expressly or impliedly allocated in . the contract. Similar arguments can be made with regard to essential reliance losses arising from so-called "unilateral" mistake. $4^{8}$ The statute should be couched in broad enough terms and the courts given sufficient discretion to include all cases involving faultless mistake or mishap..$^{49}$ By stipulating that such a statute is to apply only in those situations where the parties have failed to allocate the risk among themselves, and by enabling the court to use its discre-

at if they had contemplated the possibility of what was going to happen is, to my mind, very unsatisfactory.... It is impossible to say with any certainty what the result of their bargain would have been. See also Fuller and Perdue, op. cit. supra note io, at $38 \mathrm{r}-82 \mathrm{n}$. 107.

45 Corbin, op. cit. supra note 24 , at 8.

${ }_{4}^{6} \mathrm{Law}$ Revision Committee, Seventh Interim Report, The Rule in Chandler v. Webster (1939) at 6, appearing in I2 Reports from Commissioners, Inspectors, and Others, No. 4 (I938-9). See Corbin, op. cit. supra note 24, at 8 with regard to the power of an equity court.

47 The close relationship between mistake and impossibility in contracts cases has often been pointed out. See Sharp, Promissory Liability II, 7 Univ. Chi. L. Rev. 250, 268 (I940).

${ }^{8}$ See Extension of Relief for Unilateral Mistake, I7 Univ. Chi. L. Rev. 725 (I950).

$49 \mathrm{As}$, for example, in the case of losses arising without fault of the parties in contracts by correspondence. See Acceptance and Rejection in Contracts by Correspondence, 17 Univ. Chi. L. Rev. 375,378 (I950). See other suggestions for the application of a loss sharing principle note 26 supra. 
tion in accordance with the facts of the case and in the light of business experience and expectations, the present inequitable loss distribution schemes could be remedied without doing violence to present expectations and without impairing the present security of contracts.

The British in adopting the principle of loss sharing in the Law Reform (Frustrated Contracts) Act ${ }^{50}$ have pioneered the way. But there remains the task of providing for and adopting the use of this principle on a scale suffciently broad to include all cases where a rational and equitable allocation of losses between innocent parties may demand it.

so Note 5 supra. 